\title{
Cyclin-Dependent Kinase 5 Activator 1
}

National Cancer Institute

\section{Source}

National Cancer Institute. Cyclin-Dependent Kinase 5 Activator 1. NCI Thesaurus. Code C102497.

Cyclin-dependent kinase 5 activator 1 (307 aa, $34 \mathrm{kDa}$ ) is encoded by the human CDK5R1 gene. This protein is involved in the modulation of both kinase activity and neuronal development. 